I I UC STUDI ES

ISSN 1813-7733

Vol. - 3, December 2006 (p 19-30)

\title{
The Woman Question in the novels by the Bronte Sisters
}

\section{Rehnuma Bint Anis*}

\begin{abstract}
The Victorian period lasted more than half a century. During this time England changed radically in almost all respects. One of these was the rising consciousness of women about their rights and potentials. Soon, the social awareness was transmitted to literature. In retrospect we find that many women writers emerged at this critical juncture in history when women were pleading to be given voice, to achieve their rights and to be given an opportunity to come out of the shells of quiet submission enforced upon them and achieve something of their own. Three sisters living deep in the Yorkshire moors surprised the world by taking part in this ongoing struggle. This article attempts to evaluate their contributions towards achieving women's rights in English history.
\end{abstract}

Envious of the freedom enjoyed and the respect commanded by women during the Islamic era, Dr. Annie Bessant wrote in her book The Life and Teachings of Muhammad: 'I often think that women are more free in Islam than in Christianity. Women are more respected in Islam than by the faith which preaches monogamy' ${ }^{1}$.

For it took the women of Europe many more years and much hard struggle to attain the rights given to women by Islam centuries ago.

It was during the Victorian era that a series of changes - social, political and moral swept all over England. One of these concerned the issues of gender inequality in politics, economic life, education and social intercourse for women; rightly coming to be known as the 'Woman Question'. Within a few years it gained momentum and became just as grave an issue as evolution or industrialization. Justin M'Carthy lamented in an essay in the Westminster Review (July, 1864), 'the greatest social difficulty in England today is the relationship between men and women. The principal difference between ourselves and our ancestor is that they took society as they found it while we are self conscious and perplexed'. ${ }^{2}$

With the spread of education and the contribution of the printing press, which reduced the cost of books greatly, the nineteenth century became 'the great age of the English novel partly because the novel was the vehicle best equipped to present a picture of life lived in a given society against a stable background of social and moral values by people who were recognizably like the people encountered by readers, and this is the kind of picture of life the middle class reader wanted to read about'. ${ }^{3}$ Literature, being the mirror of society, took up the subject quickly.

As the preference for poetry changed towards a marked interest in more substantial literature, alongside the men, many women assumed the opportunity of using the life they saw around them to construct novels which would capture a picture of contemporary life as well as attract readers to identify themselves to the characters presented. N.K. Basu mentions in his essay 'Women Novelists of the Victorian Age' that the great French writer Guizot wrote, speaking of his preference for English

* Assistant Professor, Dept. of English Language and Literature, International Islamic University Chittagong. 


\section{IIUC Studies, Vol. 3}

women novelists, 'My delight is to read English novels, particularly those written by women ...... Miss Austen, Miss Ferrier, Charlotte Bronte, George Eliot, Mrs. Gaskell and many others almost as remarkable, form a school which in the excellence, the profusion, and the contemporaneousness of its productions, resembles the cloud of dramatic poets of the great Athenian age'. ${ }^{4}$ Among them were three sisters, who, in spite of living deep in the bleak and barren Yorkshire moors, surprised the world by the consciousness, expressed in their work, of the 'Woman Question'. They are Charlotte, Emily and Anne Bronte, who have won a permanent place in English literature by dint of the power and intensity of their work.

An understanding of their background is necessary to understand their work and their urge to include the 'Woman Question' in their programme. As Derek Traversi has mentioned in his essay 'The Bronte sisters and Wuthering Heights', the eldest of the three sisters, Charlotte, announced in the preface to the second edition of her most popular novel, Jane Eyre: 'Conventionality is not morality. Self righteousness is not religion ...... There is a difference; and it is a good, and not a bad action, to mark broadly and clearly the line of separation between them'. ${ }^{5}$

Charlotte (1816-55), Emily (1818-49) and Anne Bronte (1820-49) were born to Patrick and Maria Bronte in Thornton near Bradford. The family moved to Haworth in Yorkshire in 1820 where Patrick Bronte was appointed perpetual curate. Maria died in 1822 leaving her infant children motherless. A maiden sister of their mother, Elizabeth Branwell, came in to keep house and look after the children for Patrick Bronte. In 1825, Charlotte and Emily started going to Cowan Bridge School with their two elder sisters, Maria and Elizabeth. But when both the elder girls died within months of each other from the 'scourge of the century', tuberculosis, incurred due to the harsh weather of the moors, Patrick Bronte decided to educate the rest of his children at home.

Both Patrick Bronte and Elizabeth Branwell were strict disciplinarians. Perhaps this is why the children were forced to take refuge in reading, writing and living in imaginary worlds which unleashed their imaginative faculties but pushed them into severe introversion. The range of their literary reading included Blackwood's magazine, Byron, Percy and Mary Shelley, Jane Austen, Mrs. Radcliffe and some German stories in translation. In childhood, Charlotte and the only son of the family, Branwell, wove fictitous stories about some toy soldiers. When Charlotte was again sent off to school in 1831, Emily and Anne carried on the sequence with poems on the fantasized Gondal Islands.

Later on, each of the sisters found work as governess in various places. But none of them showed much interest in maintaining any intercourse with the rest of the world for any long period of time.

'In her position as elder sister and, to a large extent, as substitute for a dead mother, Charlotte's contacts with the outside world were more continuous and varied than those of her sisters'. ${ }^{6}$ She 'made an effort to come to terms with the world outside her; she allowed herself to be hurt by it, and she sought comfort in it, and this concession to a social world is reflected in the themes and structure of her novels'. ${ }^{7}$ 
Whatever the psychological explanation, Emily was more self contained though she was so dependent on her beloved moors and the close knit family for emotional sustenance that the only three times in her life she was away from home, she suffered sickness or homesickness or both; but she took it stoically and was not very expressive. However, Charlotte being an elder sister who to some extent had to play the role of a mother to her younger sisters and brother understood her better and explained, 'liberty was the breath of Emily's nostrils, without it she perished'. ${ }^{8}$ At Roehead School in Law Hill where she obtained the position of a teacher, she made it plain that 'she liked the house dog better than her pupils'. ${ }^{9}$ Charlotte said, 'I felt in my heart she would die, if she did not go home, and with this conviction, obtained her recall'. ${ }^{10}$ Anne replaced her and returning home, she never left her beloved moors again.

Anne, being the youngest, remained home while her sisters went to school, where she was influenced by her strongly Wesleyan aunt. This may have been responsible for her transformation into a 'sensitive and rather melancholy child' ${ }^{11}$ and also for her lack of vitality in comparison with her sisters. She returned home from her job as a governess after her spoilt and irresponsible brother, Branwell, who also worked in the same household raised scandals by his affairs with the employer's wife. She held herself responsible for it and lived a melancholy existence for the rest of her short life.

As the sisters returned home in 'deception and retreat' from their excursions outside the moors, they thought of establishing a school in Haworth parsonage which never saw success as the moors were so barren, harsh and empty. Then, they published a book of poems under the masculine names of Acton, Ellis and Currer Bell at their own expense. The book received a few positive reviews but unfortunately only two copies of it were sold in a few months. It was under these circumstances that they decided to pursue careers in writing novels.

But their efforts to become novelists were neither easy nor rewarded with immediate appreciation. The three sisters showed great courage and determination to publish their work. It took them many years of patient determination and waiting just to get their work printed and the two younger sisters were nearly swindled out of their money when they decided to finance their publications themselves. Their efforts yielded fruit almost contemporaneously. Jane Eyre by Charlotte, Wuthering Heights by Emily and Agnes Grey by Anne, all came out at almost the same time.

As before, the sisters used their masculine pseudonyms. Almost all female writers of the period thought it fit to assume disguises in presenting themselves to the world as novelists. Thus, their anonymity was never officially broken during their lifetime. However, it was because of their 'inwardness, their intense living to themselves' rather than fear of criticism which impelled them to maintain the secrecy concerning their identities to the very end. ${ }^{12}$ And speaking of criticism, they had more than their fair share of it, as we will learn later in this article.

Many incidents and circumstances were responsible for raising questions about the role of women in society; their privileges, their deprivations, their opportunities and their problems. One of these was the industrial revolution. Much as Bangladesh saw after the boom in our Garments Industries since the 1980s, hundreds and thousands of lower class women worked sixteen hours a day at low wages in England's textile industries alongside the men, putting 'the privileges of men to apply to the status of 


\section{IIUC Studies, Vol. 3}

women' seriously to question. ${ }^{13}$ It caused disruption in family life and challenged the traditional ideas of the woman's sphere. However, for the very same reasons, the middle class enforced a separation between 'man's work' and 'woman's work'. In either case, for the first time in English history, women became conscious of their capabilities and their rights. Even the prominent writer John Stuart Mill, in The Subjection of Women (1869), boldly challenged the long established assumptions about women's role in society, enlarging upon the ideas which first appeared in Mary Wollstonecraft's A Vindication of the Rights of Women (1792).

The only woman in the political arena at the time was Queen Victoria who considered women's suffrage, which began as early as 1840, as a 'mad folly'. 14 Thus for a long time women remained second class citizens from the political point of view, along with millions of working class men. They finally attained the right to vote in 1918.

The agitation to allow married women to own and handle their own property was less prolonged (1870 - 1908). It yielded fruit through the passing of the Married Women's Property Act. The married woman's right to own and handle property is reflected by Charlotte in Jane Eyre through the character of Jane's aunt Mrs. Reed, who inherits the estate of her dead husband and uses her property as she pleases in spite of her promises to her dead husband. A woman's right to dignity and independence where she does not choose to continue a relationship with a vicious and brutal husband, is seen in the case of Isabella in Wuthering Heights, who escapes from the clutch of Heathcliff with her son Linton in her womb and lives an independent life until her death thirteen years later; never feeling the necessity of informing her son about his father's nature or identity.

In addition to parliamentary reforms the feminists worked hard to enlarge educational opportunities for women. In 1837 none of England's three universities was open to women. But when the poet laureate Alfred Lord Tennyson participated in the ongoing struggle with his long poem The Princess (1847), fantasizing the establishment of a women's college, the collective effort was rewarded with the founding of the first women's college in London in 1848. By the end of the reign of Queen Victoria, women could take degrees at twelve universities or university colleges and could study without earning a degree at Oxford and Cambridge.

But before that, education for women was available only in finishing schools such as Miss Pinkerton's Academy in William Makepeace Thackerey's Vanity Fair or Lowood School in Charlotte Bronte's Jane Eyre. In their novels the Bronte sisters point out education as a means to develop capability as well as a tool to achieve an honourable social standing. We find that even in the remote moorland where Wuthering Heights is situated, a curate is appointed to teach the children on a regular basis. Cathy, in Wuthering Heights, is not a studious girl at all. She loves to scamper on the moors much more than reading a book. But after her five-week stay at Thrushcross Grange, she returns home as a perfect and inscrutable lady, of whom even the sceptical servant cum guardian, Nelly Dean, cannot but approve. The essential Cathy remains quite what she was, but the necessity of education for an improved, independent and dignified life does not escape her. Nelly Dean, herself a mere servant in Wuthering Heights, claims, 'I have read more than you fancy, Mr. Lockwood. You could not open a book in this library I have not looked into and got out of also ........ It is as much as you expect of a poor man's daughter'. (Chapter 7) 
Even Jane, in Jane Eyre, when she is relegated to Lowood school, where the facilities are barely enough to hold body and soul together, concentrates stoically on gathering as much knowledge and skill as she can, because she knows this will help her to survive in the world outside Lowood, which is even tougher. Agnes, in Agnes Grey, does not mind sitting with her students in order to improve her knowledge of English. However, the system of education in each case, as we see, is unformed, chaotic and inadequate. Writers as diverse as Charlotte Bronte, Elizabeth Barrett Browning and Florence Nightingale have commented that in these schools 'middle class women were taught only trivial accomplishments in order to fill up days in which there was nothing important to do'. ${ }^{15}$

In spite of the inavailability of proper educational facilities for women, agitations for improved employment opportunities for women went on. Though it was rather in consideration of the comparative physical frailty of women than women's equality that the Factory Act was passed, it corrected some of the worst aspects of women's employment in mines and factories, including reduction of the sixteen hour day.

But in even more dire straits were the half a million or more women whom the journalists termed as 'surplus' or 'redundant'; women, who remained unmarried because of the imbalance between the number of men and women in the Victorian population. Having few employment opportunities and due to bad working conditions, many of these women were driven to prostitution. The only employment option for a middle-class Victorian woman to earn a living, as well as maintain some claim to gentility, was to be employed as a governess. 'But a governess could expect no security of employment, minimal wages, and an ambiguous status, somewhere between servant and family member'. ${ }^{16}$ It is perhaps because the governess so clearly indicates the precarious condition of the unmarried middle class woman's status in Victorian England that Thackerey and Charlotte Bronte decided to explore woman's role in society by portraying the characters and plights of women employed as governesses in Vanity Fair and Jane Eyre respectively.

Jane, in Charlotte Bronte's Jane Eyre, who has spent half her life within the confines of Lowood wishes to explore the world outside and starts sending out job applications for the position of a governess. When she gets the appointment in Thornfield Hall as governess to Rochester's ward, Adele Varens, she is not only relieved but ready to go to great lengths to preserve her position; even at the cost of going to Rochester's parties, by the master's orders, where she is looked down upon by the guests. Her pay is meager but it is also her only source of income and self reliance. If she leaves it she has no one else to depend on or no other option to claim dignity. This is just as responsible for Jane's sincerity towards her job as her professionalism. Agnes, in Anne Bronte's Agnes Grey, tries her best to fit in as a teacher in the school where she works. Her dream is to establish a school of her own one day. Though in her present state of poverty and helplessness it appears to be an impossibly luxurious fancy she does not give up and rather develops her potentials in that direction for future opportunity and fulfillment. In each of these cases, education serves as a pivotal support to middle class women. For they could not work in factories or go into prostitution as these employments were not dignified, yet they had neither guardians to look after them nor a dowry to get married by. Nelly Dean is no less significant in this regard, who, in spite of being a servant is upright and plays an influential role in the story. She has the self esteem to stand up to Hindley and spit out the knife he thrusts into her mouth. 


\section{IIUC Studies, Vol. 3}

According to Sir Walter Besant, similar drives opened up a variety of professional opportunities for women in the late Victorian period, one of them being a career as a novelist. Besides that, there was the advantage of maintaining anonymity which made writing an attractive option for women who wanted to achieve something without exposing themselves to the criticism of society. In this socio-literary background, like Jane Austen, George Eliot, Elizabeth Gaskell and many others, the three Bronte sisters too determined to carve a niche for their creative faculty by writing and publishing novels.

In choosing their female protagonists, women who would represent their thoughts and attitudes, they prefer capability to beauty. At a time when, as Mrs. Oliphant has said, it was the convention to expect the heroine in a novel, 'in white muslin, the immaculate creature who was of sweetness and goodness all compact', ${ }^{17}$ Charlotte makes Jane intentionally unattractive and not much gifted. But from the very first moment we meet the sickly, unloved child we are attracted by her love of reading. This studiousness is later strengthened further by her aquaintance with Helen Burns in the boarding school. Cathy, when we first meet her in Wuthering Heights, in her wild and tempestuous nature seems to be 'the very embodiment of the wind swept moors, reveling in all the bleakness, the loneliness, the storm-tossed vicissitudes of that countryside'. ${ }^{18}$ She is too strong either to be tamed or to be adored. But the aura of power in her character, even as a child, is unmistakable. Though plain, petite, timid and unimpressive in appearance, Agnes' quiet determination to succeed as a teacher and her painstaking efforts in that direction do not escape notice. The interesting fact in the case of each of these women is that the strength of character of the Bronte sisters seems to seep into their women through their pen giving them life and animation. The women are so strong in their belief on their dreams that they will give up life rather than leave the purpose of their life unfulfilled.

Women are essentially homebuilders, and in spite of their urge for dignity and freedom they need someone to love, to care for; someone who appreciates them as a human being rather than as a paragon of beauty. It is perhaps due to their secluded lives, that in each book that the Bronte sisters wrote, the women fall in love with the first eligible male character who presents himself on the scene. In spite of the strong character of Jane Eyre as portrayed by Charlotte, 'there are times, indeed, when this self reliant integrity is in danger of being submerged by the surge of less controlled feeling'. ${ }^{19}$ Given the circumstances of the Victorian society, however, it is not surprising that Jane should consider Rochester's proposal seriously. Being a woman, part of Charlotte's nature 'moves her to present an idealized picture of the emotion which draws her female characters to their men; but, and often at the same time, another part, aware of excess and absurdity, is capable of presenting a realistic, even a disenchanted picture of the male objects of their devotion'. ${ }^{20}$ Jane is quite levelheaded when she discovers that Rochester has a 'concealed mad wife'. The institution of marriage concealed 'disconcerting and bitter realities' ${ }^{21}$ which Charlotte was not afraid to expose. Being the puritanical daughter of a puritanical father she never loses control of her fears and phobias as does the character of Miss Havisham in Charles Dickens' Great Expectations. 'There is no touch of lawlessness in her passions'. ${ }^{22}$ So, when Rochester, failing to marry Jane legally, proposes to her to become his mistress, she not only refuses but also resigns her position in his house and finds another situation. This capacity to take responsibility in adverse situations was one of the chief features which gained women the rights they wished for. Yet she 
marries him when he is physically and financially reduced by the accident which kills his wife. 'Many readers were shocked that Rochester, who tried to make Jane his mistress, should be rewarded by marrying her. Some readers were also shocked because Jane wanted to be regarded as a thinking and independent person rather than a weak female'. ${ }^{23}$ But here we must consider the fact that Rochester's love for Jane was genuine, as she was neither attractive, nor able to pay a dowry, nor eligible for a man in his position when he first proposed to her. He befriended her when she had none. So, Jane too had sincere regards for him and could not forget him. This encouraged her to marry him even when she was at an advantage and he was not. She realized that he was the victim of a very unusual dilemma but there was no pretension in his love and this enabled her to live happily ever after with the man she loved, by an acceptance of situations only true love can bring. In this way, through Jane, Charlotte has 'proclaimed the rights of her sex 'to give expression to her desire' unwilling to await meekly the initiative of the male'. ${ }^{24}$

The world explored in Emily's Wuthering Heights is much narrower than in Charlotte's Jane Eyre, and its emotional intensity, 'the product of a unique concentration upon fundamental human passion in a state approaching essential purity ${ }^{25}$ makes the concept of love explored in the novel quite different. The word 'love' is painfully inadequate to define what Cathy and Heathcliff feel for each other, though she never refuses the name of 'love' for the feeling she has for Edgar Linton. She is attracted by Linton's courtesy, charm and urbanity. But what she feels for Heathcliff is best summed up by what she says to Nelly, in comparing her feelings for the two men: 'Nelly, I am Heathcliff'. (Chapter 9) In her reflections she is aided by Nelly Dean, who, 'guided by inherent sense of reality and by her longer if not particularly imaginative experience of life, maintains that Edgar is a good match, socially speaking acceptable and likely to bring her domestic happiness, whereas devotion to Heathcliff can only end is disaster and degradation'. ${ }^{26}$ But to Cathy the difference between the two options is like 'a contrast between the agreeable and the necessary, between emotions which serve to adorn life and others whose absence is felt, at a level at once deeper and more dangerous, to be equivalent to the death of the spirit'. ${ }^{27}$ Yet she chooses to marry Edgar, adding, 'In whichever place the soul lives in my soul, and in my heart, I'm convinced I'm wrong'. (Chapter 9) 'Her knowledge of herself is therefore a mixture of mature self appraisal and immature evaluation of it, so that her actions undermine the certainty of her beliefs'. ${ }^{28}$ As a result, she lives on two levels, one is in her marriage to Edgar which is a social necessity and the other in Heathcliff which is equivalent to her spiritual existence. But it breeds the dilemma of the woman who wants it all. Edgar, in spite of being a loving and indulgent husband, cannot accept the fact that the soul of the woman he possesses as his wife belongs to someone else; and that someone he hates. Isabella too mistakes Cathy's warnings against Heathcliff as jealousy. The relationship between Cathy and Heathcliff, being spiritual rather than physical, was perplexing even to Charlotte. She found it incomprehensible, for 'the moral law which separates Jane from Rochester could not exist in the relationship of Catherine Earnshaw, later Linton and Heathcliff'. ${ }^{29}$ Unable to effect a union between her two opposing desires, Cathy chooses to 'break both their hearts by breaking my own'. (Chapter 11) But as Graham Handley points out, Cathy has one redeeming feature, 'she has moments of lucid self analysis and intuitive self recognition which are beyond the range of the conventional heroine'. ${ }^{30}$ Ultimately the conflict between the two opposing forces as symbolized by the two houses in Wuthering Heights is resolved in the union between Hareton Earnshaw and Catharine Linton 'drawn together over the pages of their book 


\section{IIUC Studies, Vol. 3}

and moving, tentatively and with an underlying gesture of reborn trust, towards mutual understanding'. ${ }^{31}$ Thus, Emily shows us love in both extraordinary and ideal forms. Incidentally, she also paints an interesting caricature of love in the case of Lockwood who has run away from his commitment to the lady he meets only to fall for Catherine Linton whom he finds too fiery for his delicate taste.

Agnes, in comparison, has a very ordinary love affair and exhibits a marriage which is a fusion between the comfortable and the convenient. It is not that she does not suffer for love but it is neither as extravagant nor as colourful as Cathy's or Jane's love relationships, for she is too pliant and submissive to dramatize her emotions as the others.

Charlotte's Jane Eyre is the story of an ordinary orphan girl who struggles her way to finding happiness and fulfilment in life. Today the novel appears to have more of romantic fantasy than realism; but it is unfair to condemn it as a novel of escape because through this novel Charlotte Bronte became the first English novelist 'to bring the note of intimacy'. ${ }^{32}$ As Daiches says, 'Parts of the book are practically straight autobiography and other parts represent the kind of wish fulfillment which few Victorian women had the courage or the power to translate into fiction'. ${ }^{33}$ Compton-Rickett points out, 'writing from the woman's point of view, which no woman before her dared to do, she has written of 'lonely, repressed woman with a passion and intensity unsurpassed in English fiction, even among the outspoken fiction of our own day'. ${ }^{34}$ But the critical reaction to the novel during her lifetime was merciless. Even a man of letters like Robert Southey was so bitter in his criticism that he almost succeeded in making Charlotte Bronte stop writing. And even the contemporary women such as Margaret Oliphant called the novel 'a wild declaration of the 'Rights of Woman' in a new aspect' whereas Elizabeth Rigby attacked its 'pervading tone of ungodly discontent'. ${ }^{35}$ But she was not to be extinguished so easily. Ultimately she went on to write three more novels, The Professor, Shirley and Villette. However, Jane Eyre remains her most popular novel.

Emily's Wuthering Heights is a story of passionate love and cruel revenge between larger than life characters in a remote setting and an environment which is as wild as the emotions which are displayed in it. When it first appeared, it was called 'devilish' and 'irremediably monstrous'. ${ }^{36}$ Charlotte herself was confused as to the implications of the novel in trying to defend her sister from adverse criticism. It was even compared with Gothic melodrama, but 'the capacity to effect an intimate fusion between the thing seen, or the felt sensation, and its emotional interpretation has enabled her to raise a melodramatic story to the level of a deeply personal creation'. 37 Today it is accepted by all as a brilliant work of genius appreciated in the following terms:

'no other novel of the Victorian period has penetrated so undisguisedly into the depths of unalloyed passion, or followed with such unrelenting logic the intensity of its operations. The result is a unique imaginative creation which, largely ignoring the moral and social assumptions of contemporary fiction, aspires rather to the simplicity of ancient tragedy, ${ }^{38}$

In her novel, Emily used her beloved moors for a setting and her genius sufficed for the development of the plot and characters. Wuthering Heights remains her only novel as she died while she was working on a second novel. 
Anne's Agnes Grey is a woman who is not content to win a husband and a home alone but cherishes a hope of achieving something more in life. In fact, perhaps she is the closest of all the characters created by the sisters, to the modern woman, in her aspirations and needs from life. But for that very reason, Anne has had to defend herself in the preface to The Tenant of Wildfell Hall, the second of her two novels, saying, '.......... the story of Agnes Grey was accused of extravagant overcoloring in those very parts that were carefully copied from the life, with the most scrupulous avoidance of all exaggeration..... ${ }^{39}$ She drew on her experiences as a governess to the over privileged children of the houses where she worked for material in her novels. She shared the passionate introversion of her sisters but lacked their imaginative vitality. Though her work has a few powerful moments they offer 'little which is not better appreciated in the two greater works'. ${ }^{40}$

The novels of the three sisters express 'those private passions and explore those realms of personal emotion which, in another age, would have been more likely to seek expression in lyrical poetry'. ${ }^{41}$ Thus, their prose has a poetic texture and an intensity of the interplay of emotion which draws the reader magnetically over the pages of the novels.

Derek Traversi has observed in The Literature of the Victorian Era about Charlotte's prose style:

'The best pages of these novels are ......... very far from negligible. They are those in which Charlotte is able to recall her own experiences most vividly, and in which her own more intimate feelings, her lifelong need for emotional compensation, are least directly involved'. ${ }^{42}$

We cannot but admit that, at times, Charlotte tends to get a bit tedious and absurd.

But Emily's prose is 'firm and biting and the action is deployed through the cunning interposition of intermediate narrators in such a way as to emphasize at once the uniqueness and the power of this strange and compelling series of events'. ${ }^{43}$ Two examples will suffice. In the opening lines of the first chapter, the description of Wuthering Heights has an uncanny resemblance to its owner, Heathcliff's character, which sets the mood of the story immediately. And when the lively Catherine Linton and the sickly Linton Heathcliff discuss their conceptions of the best way to pass a hot summer's day, it turns into two contrasted ideas of celestial happiness. Nature is seen in Wuthering Heights in all its beauty and power. The human beings too are powerfully drawn. They are individually identifiable even from the way they speak.

Nowhere do the sisters appear to be inferior in their craft than their male counterparts of the time. Rather, the male novelists hardly ever used their voice to protest against the repression faced by women or use their pens to ask for the rights of women. In fact, the women portrayed by the male novelists are prototypes, like the soft and submissive Lucy in The Tale of Two Cities by Charles Dickens.

It is clear from the above review that the attack which the sisters faced from contemporary critics is based not so much on their quality as writers as the Victorian concept of womanhood, which stressed 'woman's purity and selflessness. Protected 


\section{IIUC Studies, Vol. 3}

and enshrined within the home, her role was to create a place of peace where man could take refuge from the difficulties of modern life'. ${ }^{44}$ But the sisters encouraged the 'Woman Question' by bringing out in their work that, 'the problem was not so much political, economic and educational as how women were regarded or how they regarded themselves as members of the society'. ${ }^{45}$ In their novels they emphasized; firstly, on capability rather than beauty; secondly, on the necessity of education for women; thirdly, they indicated employment as a means of independence and self reliance for women; and last but not least, they proclaimed the right of a woman to state her own feelings.

Florence Nightingale chose to leave a life of comfort and live a productive life as well as revolt against a repressive society by becoming a nurse and joining hospital administration. Similarly, writing was the Bronte sisters' mode of claiming the rights of women. It was women like them who finally humbled Victorian men to admit, as George Meredith did in his Essay on Comedy (1873), 'the test of a civilization is whether men consent to talk on equal terms with their women, and to listen to them'. ${ }^{46}$

But today we see many women carrying the hard won rights of women to such great lengths as make us wonder if this is what the Victorian women really had in mind when they asked for freedom. As a Bangla proverb says, 'it is more difficult to maintain liberty than to win it'. Using the liberty women have earned for unfair advantage or financial benefits demeans its worth. So, the best way to pay tribute to the predecessors of so many women who enjoy freedom all over the world today, is to go forward maintaining those moral and social bindings which once helped the Victorian women to break out of male tyranny and yet earn their respect.

\section{References}

1. Muhammad, Farkhanda Noor (2002), Respect for Women in Islam, Islamiyat for Students, Lahore, Ferozson's (Pvt) Ltd., p 160

2. M’Carthy, Justin (1864), Westminster Review, London

3. Daiches, David (1969), A Critical History of English Literature, London, Secker and Warburg, Volume IV, p 1049

4. $\quad$ Basu, Nitish Kumar (1998), Advanced Literary Essays, Calcutta, Presto Publishers, p 314

5. Traversi, Derek (1996), The Bronte Sisters and Wuthering Heights, The New Pelican Guide to English Literature, Edited by Boris Ford; London, Penguin Group, Volume 6, p 248

6. ibid, p 247

7. Daiches, David (1969), A Critical History of English Literature, London; Secker and Warburg, Volume IV, p 1066

8. Basu, Nitish Kumar (1998), Advanced Literary Essays, Calcutta, Presto Publishers; p 320

9. Handley, Graham (1987), Introduction, Wuthering Heights, London; Macmillan Education Ltd.; p xi

10. ibid, p xi 
The Woman Question in the novels by the Bronte Sisters

11. Introduction (1994), The Tenant of Wildfell Hall, London, Penguin Group, p 9

12. Daiches, David (1969), A Critical History of English Literature, London, Secker and Warburg, Volume IV, p 1064

13. The Norton Anthology of English Literature (1993), New York, W.W. Norton and Company Inc; Volume 2, p 902

14. ibid, p 1595

15. ibid, p 903

16. ibid, p 903

17. Basu, Nitish Kumar (1998), Advanced Literary Essays, Calcutta, Presto Publishers, p 315

18. ibid, p 320

19. Traversi, Derek (1996), The Bronte Sisters and Wuthering Heights, The New Pelican Guide to English Literature, Edited by Boris Ford, London, Penguin Group, Volume 6, p 250

20. ibid, p 250

21. ibid, p 251

22. Basu, Nitish Kumar (1998), Advanced Literary Essays, Calcutta, Presto Publishers, p 319

23. World Book Encyclopedia (1996), Chicago, World Book Inc., Volume B, p 587

24. Basu, Nitish Kumar (1998), Advanced Literary Essays, Calcutta, Presto Publishers, p 319

25. Traversi, Derek (1996), The Bronte Sisters and Wuthering Heights, The New Pelican Guide to English Literature, Edited by Boris Ford, London, Penguin Group, Volume 6, p 247

26. ibid, p 256

27. ibid, p 255

28. Handley, Graham (1987), Introduction, Wuthering Heights, London, Macmillan Education Ltd., p xviii

29. ibid, p xiii

30. ibid, p xvi

31. Traversi, Derek (1996), The Bronte Sisters and Wuthering Heights, The New Pelican Guide to English Literature, Edited by Boris Ford; London; Penguin Group; Volume 6, p 261

32. Basu, Nitish Kumar (1998), Advanced Literary Essays, Calcutta; Presto Publishers; p 319

33. Daiches, David (1969), A Critical History of English Literature, London; Secker and Warburg; Volume IV, p 1065

34. Basu, Nitish Kumar (1998), Advanced Literary Essays, Calcutta; Presto Publishers; p 319

35. The Norton Anthology of English Literature, 1993; New York; W.W. Norton and Company Inc; Volume 2, p 1597

36. Handley, Graham (1987), Introduction, Wuthering Heights, London; Macmillan Education Ltd.; backcover

37. Traversi, Derek (1996), The Bronte Sisters and Wuthering Heights, The New Pelican Guide to English Literature, Edited by Boris Ford; London; Penguin Group; Volume 6, p 254

38. ibid, p 253 


\section{IIUC Studies, Vol. 3}

39. Bronte, Anne, Preface to the Second Edition, The Tenant of Wildfell Hall; 1848; London; Penguin Group

40. Traversi, Derek (1996), The Bronte Sisters and Wuthering Heights, The New Pelican Guide to English Literature, Edited by Boris Ford; London; Penguin Group; Volume 6, note 2, p 262

41. The Norton Anthology of English Literature, 1993; New York; W.W. Norton and Company Inc; Volume 2, p 1064

42. Traversi, Derek (1996), The Bronte Sisters and Wuthering Heights, The New Pelican Guide to English Literature, Edited by Boris Ford; London; Penguin Group; Volume 6, p 316

43. Daiches, David (1969), A Critical History of English Literature, London; Secker and Warburg; Volume IV, p 1066

44. The Norton Anthology of English Literature, 1993; New York; W.W. Norton and Company Inc; Volume 2, p 904

45. ibid, p 904

46. ibid, p 1597 